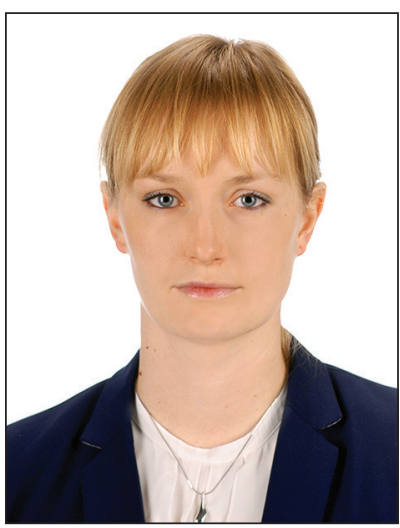

Lewandowska Ewa,

PhD in Law, Department of Civil Law

and Private International Law,

Faculty of Law and Administration,

University of Warmia and Mazury in Olsztyn,

Poland

e-mail:ewa1bieniek@gmail.com;

e.lewandowska@uwm.edu.pl

ORCID 0000-0001-8369-6290

\author{
doi: 10.21564/2414-990x.150.205798 \\ UDC 347.78(438):341.9
}

\title{
ON COPYRIGHT TROLLING IN THE FRAMEWORK OF CIVIL LAW
}

The paper analyses copyright trolling in the scope of illegitimate compensation claims for a breach of the author's economic rights, i.e. where: 1) no infringement of economic rights has occurred, or 2) the action has been brought before the wrong authorities, or 3) the claimant has no title to bring the action before the court. It was noted that the use of copyrighted works requires the consent of the owner of economic rights, or such a use as an exception is possible in the form of permissible use. If a work is used under a contract or the law, no infringement occurs. It outlines cases of a breach of the author's economic rights in the Polish law and the protection measures available to the entitled party in the event of an infringement. In particular, according to Art. 79 of the Copyright Law, the injured party may generally demand that the person who infringed upon the economic rights (the offender): 1) ceases the infringement; 2) removes the effects of the infringement 3) redresses the damage: under general conditions or by paying double the amount due if the owner had consented to the use; 4) renders the obtained benefits. A copyright troll calls the recipient to redress the damage by paying an appropriate sum, which is the owner's right in the event of an infringement. Copyright troll falsely relying on the fact of infringement, while acts to obtain undue benefits.

Furthermore, it discusses the term of "copyright trolling" and its scope. A significant conclusion is that copyright trolling is an action of exploiting copyright infringement and the related protection measures to obtain material gain (extort money). The paper offers an assessment of the phenomenon in the framework of civil law, focusing primarily on the legal basis for the return of the performance / redressing the damage. The basis for the return is provided by regulations on unjust enrichment. It is observed that the circumstances of copyright trolling allow for claiming infringement upon personal interests, such as privacy, peace, the right not to be disturbed, the inviolability of the home. This work aims to contribute to the growing body of literature on copyright trolling. The author especially hopes to initiate an informed discussion based on research, which could have the additional benefit of educating the public on the subject.

Keywords: copyright trolling; author's economic rights; declaration of intent; contract; delict; personal interests.

Левандовсъка $\boldsymbol{G}$., кандидатка юридичних наук, кафедра цивільного права і міжнародного приватного права, факультет права і адміністрування, Вармінсько-Мазурський університет в Ольштині.

e-mail: ewa1bieniek@gmail.com ; e.lewandowska@uwm.edu.pl ; ORCID 0000-0001-8369-6290 
Про тролінг авторських прав у рамках цивільного законодавства

У статті аналізується тролінг авторських прав у межах неправомірних вимог про відшкодування шкоди за порушення економічних прав автора, тобто коли: 1) не відбулося порушення економічних прав, або 2) позов подано проти неправильних органів влади, або 3) позивач не має права на пред'явлення позову до суду. Було зазначено, що для використання захищених авторським правом творів потрібна згода власника господарських прав, або таке використання як виняток можливе у формі дозволеного використання. Якщо твір використовується за контрактом або законом, порушення не відбувається. У ньому викладені випадки порушення економічних прав автора в польському законодавстві та заходи захисту, доступні правомочній стороні у разі порушення. Зокрема, згідно зі ст. 79 Закону про авторське право, потерпіла сторона може взагалі вимагати від особи, яка порушила економічні права (правопорушник): 1) припинити порушення; 2) усуває наслідки порушення; 3) відшкодовує шкоду: за загальних умов або шляхом сплати подвійної суми, якщо власник дав згоду на використання; 4) надає отримані переваги. Авторсвкий троль закликає одержувача відшкодувати шкоду, сплативши відповідну суму, що є правом власника у разі порушення. Авторський троль помилково покладається на факт порушення, одночасно діючи для отримання невиправданих вигод.

Крім того, вона обговорює термін «авторське тролінг» та його сферу застосування. Важливим висновком є те, що тролінг за авторським правом - це дія з метою порушення авторських прав та пов'язаних із цим заходів захисту для отримання матеріальної вигоди (вимагання грошей). У статті пропонується оцінка явища в рамках цивільного законодавства, зосереджуючись насамперед на правовій основі для повернення результатів/відшкодування шкоди. Підставою для повернення є нормативні акти про безпідставне збагачення. Зазначається, що обставини тролінгу авторських прав дозволяють заявити про порушення в інтересах особистих інтересів, такі як приватність, мир, право не турбувати, недоторканість будинку. Ця робота спрямована на те, щоб сприяти зростанню літератури про тролінг авторських прав. Автор особливо сподівається розпочати усвідомлену дискусію на основі досліджень, яка могла б мати додаткову користь в освіті громадськості з цього питання.

Ключові слова: тролінг авторських прав; економічні права автора; декларація про наміри; договір; делікт; особисті інтереси.

\section{Introduction}

\section{Problem setting}

Copyright is a relatively new branch of the law and, as the society has entered the age of digital and information technology, it is becoming even more difficult to interpret. The review of a claim of copyright infringement that occurs on the Internet requires both expertise in copyright protection and an understanding of the technological process involved ${ }^{1}$. The issue is far from evident for theoreticians and practitioners of the law, let alone others.

On one hand, the vastness of the Internet and the plethora of permitted use exceptions (that allow free use of the work) usually hinder the efforts of copyright owners to monitor the situation, identify infringements and enforce their rights. On the other, Internet users often do not know whether or not their use of sources (movies, music) published online constitutes a copyright infringement. Ignorance and unawareness in the matters of copyright law create opportunities for the abuse

\footnotetext{
${ }^{1}$ See: Zygmunt, J. (2017). Przesyłanie plikyw za pośrednictwem sieci peer-to-peer a rozpowszechnienie utworu w rozumieniu prawa autorskiego. Zeszyty Naukowe Uniwersytetu Jagiellońskiego, No. 1, 2017, p. 44 et seq.
} 
of rights, which proves the importance of educating the public and warning against dangerous practices ${ }^{1}$.

\section{Analysis of recent research and publications}

The paper discusses "copyright trolling", which is a type of fraud ${ }^{3}$. In general, the practice involves sending in bulk pre-litigation demands for a payment which is presented as a compensation for illegal downloads, i.e. for an infringement upon the author's economic rights. The emails are sent to random people (Internet users), identified by their IP address, and usually bear counterfeit stamps of a law firm to project an image of trustworthiness. Their contents are usually drafted with recourse to a variety of social engineering techniques such as a threat of court proceedings (which entail an additional risk of substantial costs), statutory damages and criminal liability. The sender has no intention of actually pursuing claims in civil litigation, aiming only to obtain compensation by inspiring fear, uncertainty and doubt. Copyright trolls are often successful in their efforts. Experience shows that recipients often meet the demands, not because they have committed the infringement, but because of their ignorance of the law. It is uncommon for recipients to judge a demand on its merits or ignore it as a kind of fraud or an extortion attempt. Besides, their perception of the legal system often becomes an additional incentive to fall victim to the fraud. The media describe legal proceedings as a long and onerous process that requires evidence to be presented. Meanwhile, the accused of the alleged infringements have no evidence to prove their innocence apart from their own words ${ }^{4}$.

\section{Statement of the article objective}

The scope of this paper is limited to the analysis of illegitimate compensation claims for a breach of the author's economic rights, i.e. when 1) no infringement of economic rights has occurred, or 2) the action has been brought before the wrong authorities, or 3) the claimant has no title to bring the action before the court. Such a definition of the scope requires determining situations that constitute infringement upon economic copyrights, protection measures available to the owner, the meaning of copyright trolling and to perform an assessment of the phenomenon in the framework of civil law.

\footnotetext{
${ }^{1}$ Compare for instance: https://www.gov.uk/government/publications/letters-alleging-onlinecopyright-infringement/letters-alleging-online-copyright-infringement, 19.11.2019.

${ }^{2}$ For instance: Wall, D.S. (2015). Copyright trolling and the policing of intellectual property in the shadow of law. The SAGE Handbook of Intellectual Property, M. David and D. Halbert, (eds), London: SAGE, 2015, pp. 607-626; Curran, L.S. (2013). Copyright Trolls, Defining the Line Between Legal Ransom Letters and Defending Digital Rights: Turning Piracy into a Business Model or Protecting Creative from Internet Lawlessness?, 13 The John Marshall Review of Intellectual Property Law 170, 2013, p. 172.

${ }^{3}$ According to Katarzyna Grzybczyk, this situation is only one possible form of copyright trolling, Grzybczyk, K. (2019). Ikony popkultury a prawo własności intelektualnej. Jak znani i sławni chronią swoje prawa, Warsaw: Wolters Kluwer, 2019, p. 25.

${ }^{4}$ In accordance with Art. 6 of the Act of April 23, 1964, The Civil Code (consolidated text, Dz.U. of 2019, item 1145, as amended), hereinafter: the CC, the burden of proof rests on the party which attributes legal effects to a fact; implying that it is the party requesting payment that should prove the infringement upon the author's economic rights.
} 
To draw attention to the situation of the recipients, the paper outlines the basis for demanding the return of the performance rendered and considers whether, in the circumstances of copyright trolling, the injured party is entitled to claim infringement upon personal interests. Such a perspective is uncommon in the academic world literature on the issue, as observed by Brad A. Greenberg ${ }^{1}$. This work aims to contribute to the growing body of literature on copyright trolling. The author especially hopes to initiate an informed discussion based on research, which could have the additional benefit of educating the public on the subject.

\section{Presentation of the main body of the article}

2. Infringement upon the author's economic rights and available protection measures as found in the Polish law

Copyright law is concerned with works, i.e. any manifestation of the creative activity of individual nature, established in any form, irrespective of its value, designation or manner of expression (Art. 1 of the Act on Copyright and Related Laws ${ }^{2}$. The Polish Copyright Law establishes a dualistic structure of copyrights, distinguishing moral and economic rights ${ }^{3}$. In reality, their nature is neither unambiguously moral nor economic. This paper discusses only economic rights.

In civil law, the author's economic rights are the subject matter of dispositive contracts (for the transfer of rights) and license contracts (for the use of rights). Furthermore, economic rights may be transferred by inheritance ${ }^{4}$ (Art. 41 of the Copyright Law) and generally expire after the lapse of seventy years from the death of the author (compare: Art. 36 of the Copyright Law). Decisions on the use and disposal of the work are made by the owner of copyright, who is usually the author but, since the rights are transferable, may also be another civil-law entity. With reservation to legal restrictions, the parties are free to form contracts as they see fit. The use of work shall be limited in accordance with contractual provisions, whose breach shall constitute an infringement upon the author's economic rights.

In general, the use of work requires the consent of the owner of economic rights. However, Polish legislation foresees an exception to this principle in the form of permissible use. Established in Art. $23-35^{12}$ of the Copyright Law ${ }^{5}$, permissible use of copyrighted works is a legal restriction of the author's monopoly, introduced to the benefit of other entities since it does not require the author's consent. Unless the

\footnotetext{
${ }^{1}$ Greenberg observes that little scholarship has addressed measures for mitigating the harms trolls pose; Greenberg, B.A. (2014). Copyright trolls and presumptively fair uses. University of Colorado Law Review, Vol. 85, 2014, p. 56.

2 Act of February 4, 1994 on Copyright and Related Rights (consolided text, Dz.U. of 2019, item 1231, as amended), hereinafter: the Copyright Law.

${ }^{3}$ See: Jankowska, M. (2011). Autorstwo i prawo do autorstwa, Warsaw: Wolters Kluwer, 2011, p. 84 et seq., Nowicka, A. (2013). System Prawa Prywatnego, Prawo autorskie, Vol. 13, J. Barta (ed.), Warsaw: C.H. Beck, 2013, p. 82, Judgment of the Administrative Court in Poznań of November 7, 2007, case reference No. I ACa 800/07 (lex database, No. 370747).

${ }^{4}$ See: Ślęzak, P. (2007). Dziedziczenie praw majątkowych w świetle polskiego prawa autorskiego. Rejent, No. 1, 2007, p. 97.

${ }^{5}$ See: Preussner-Zamorska, J., Marcinkowska, J. (2013). System Prawa Prywatnego, Prawo autorskie, Vol. 13, J. Barta (ed.), Warsaw: C.H.Beck, 2013, p. 491.
} 
Copyright Law states otherwise (rare exceptions), permissible use entitles the author to no compensation. However, it does require the user to respect the author's moral rights, i.e. to identify the author's full name and the source (Art. 34 of the Copyright Law), bearing in mind the existing possibilities of retrieving such information. Permissible use must not infringe upon the normal use of the work or violate the rightful interests of the author (Art. 35 of the Copyright Law). Permissible use includes the special case of private use (Art. 23 of the Copyright Law), which does not involve public dissemination. However, the Copyright Law does not authorize to build constructions according to other authors' works in the field of architecture and architecture and town planning or to use electronic databases constituting works unless this refers to one's own use for scientific purposes, which is not related to any profit-gaining activity. The scope of the private use shall cover the use of single copies of the work by a group of persons staying in a personal interrelation with each other, particularly including blood relations, kinship or a social relationship.

If a work is used under a contract or the law, no infringement occurs. Contrarily, if the author's monopoly is challenged without a legal or contractual basis (exceeding the scope of empowerment), knowingly or otherwise, such an action constitutes an infringement upon the author's economic rights ${ }^{1}$. The law foresees relevant measures for the protection of said rights. The fundamental provision in this regard is Art. 79 of the Copyright Law. As implied by its contents, as well as the diversity of possible factual states, the general provisions of the Polish Civil Code (hereinafter: the CC) are also applicable.

According to Art. 79 of the Copyright Law, the injured party may generally demand that the person who infringed upon the economic rights (the offender): 1) ceases the infringement; 2) removes the effects of the infringement 3) redresses the damage: under general conditions (e.g. Art. 415 of the CC, along with Art. 361.2 and 361.1 of the CC) or by paying double the amount due if the owner had consented to the use ${ }^{2}$; 4) renders the obtained benefits. In the cases of infringement upon the author's economic rights, redressing the damage by way of natural restitution seems impossible, so the liability to indemnify shall always involve paying an appropriate sum. Irrespective of the foregoing, the injured party may demand a single or multiple press announcements having the proper wording and form, or the communication to the public of all or a part of the court ruling issued in the examined case, in the manner and within the scope defined by the court (Art. 79.2 of the Copyright Law). In addition, if the breach is non-culpable, the court may instruct the offender, at their request and with the consent of the injured party, to pay an appropriate sum to the injured party if discontinuance of the breach or elimination of its consequences

\footnotetext{
${ }^{1}$ See: Bogdalski, P. (2003). Środki ochrony autorskich praw majątkowych oraz ich dochodzenie w świetle prawa polskiego, Warsaw: Wolters Kluwer, 2003, pp. 24-27.

2 See: judgment of the Constitutional Tribunal of June 23, 2015, case reference No. SK 32/14 (lex database OTK-A 2015/6/84), wherein the Constitutional Tribunal has ruled that the contents of the cited provision within the scope of redressing the damage by paying triple the amount of the remuneration due are unconstitutional.
} 
would have been excessively onerous for the offender (Art. 79.3 of the Copyright Law). When declaring a breach of the law, the court may adjudge, at the owner's request, on illegally produced objects and means and materials used to produce them and in particular, on their withdrawal from trading, on assigning them to the owner as part of damages, or on their destruction. While issuing its decision, the court shall take into account the weight of the breach and third-party interests (Art. 79.4 of the Copyright Law). It shall be presumed that the said means and materials are owned by the person who breached the author's economic rights (Art. 79.5 of the Copyright Law).

The claim to redress the damage inflicted is not limited to the amount of remuneration that the offender has failed to pay. The damage may include both damnum emergens and lucrum cessans, i.e. respectively a reduction in assets (failure to gain compensation) and the failure to increase the assets (loss of the expected profits due to infringement). The principle of full indemnification for the loss sustained and a ban on unjust enrichment as a result of the damages awarded are both applicable ${ }^{1}$. The claim for damages obliges to demonstrate the loss and prove its value. As stated in Art. 6 of the CC, the burden of proof rests on the claimant.

A copyright troll calls the recipient to redress the damage by paying an appropriate sum, which is the owner's right in the event of an infringement. However, note that the troll's behavior is illegitimate because: 1) no infringement of economic rights has occurred, or 2) the action has been brought before the wrong authorities, or 3 ) the claimant has no title to bring the action before the court.

\section{Contemplation on the scope of copyright trolling}

\subsection{Aspects of the definition}

Copyright trolling is a new and catchy term ${ }^{2}$, yet undefined in the framework of the Polish law. The phenomenon lacks a uniform, general definition also in Polish and world literature. Researchers tend to define copyright trolling for the purposes of each publication individually. For example, Olga Wrzeszcz believes that copyright trolling involves "the actions of persons entitled or potentially entitled to dispose of economic copyrights that involve threatening, blackmail, or other forms of pressure to arrange a settlement and thus obtain material gain from a person who potentially infringes upon economic copyrights on the Internet"3. David S. Wall observes that "the phenomenon of 'copyright trolling' is the (il)legal practice, sometimes called 'creative lawyering', 'unprofessional', often referred to as 'speculative invoicing' that sows discord and seeks to either upset or embarrass people so that they will pay for downloaded material"4.

\footnotetext{
${ }^{1}$ Jankowska, M. (2017). Ustawa o prawie autorskim i prawach pokrewnych. Komentarz, P. Ślęzak (ed.), Warsaw: C.H. Beck, 2017, p. 542.

${ }^{2}$ It is worth noting that American copyright law has for long enabled behavior that is only today described as "trolling", Balganesh, S. (2013). The Uneasy Case Against Copyright Trolls. 86 Southern California Law Review, 723 (2013), http://ssrn.com/abstract=2150716 (20.12.2019).

${ }^{3}$ Wrzeszcz, O. (2016). Trolling prawnoautorski (copyright trolling). Zeszyty Naukowe Uniwersytetu Jagiellońskiego. Prace z prawa własności intelektualnej, No. 134, 2016, p. 45.

${ }^{4}$ Wall, D.S. (2015). op.cit. pp. 607-626.
} 
Any civil-law entity may be a copyright troll, natural and legal persons included. The recipient will be more likely to meet the demands if the request comes from a larger organization entered into an official register. The term "copyright troll" may refer to entities either bearing the author's economic rights or having no rights at all $^{1}$. In cases of copyright infringement, legal action may be rightfully brought before the court by an entity which has owned the author's economic rights at the moment of the infringement. Such an entity may be the author or another copyright owner entitled under special provisions (compare: Art. 12 of the Copyright Law), and their legal successors who have acquired said rights or the right to bring lawsuits under a contract for the transfer of rights or for an exclusive license ${ }^{2}$. For instance, Luke S. Curran assumes that a copyright troll is "a non-producer who merely has acquired the right to bring lawsuits against alleged infringers" who takes an action that "threatens to file copyright infringement claims in order to induce rapid settlements against large groups of anonymous defendants without the intention of proceeding to trial on the merits"3. Brad A. Greenberg in his paper defines a copyright troll as "a copyright owner who: (1) acquires a copyright-either through purchase or act of authorship-for the primary purpose of pursuing past, present, or future infringement actions; (2) compensates authors or creates works with an eye to the litigation value of a work, not the commercial value; (3) lacks a good faith licensing program; and (4) uses the prospect of statutory damages and litigation expenses to extract quick settlements of often weak claims"'.

A literature review suggests that copyright trolling is characteristic in the manner and motives of the offender. In principle, copyright trolls use blackmail or other forms of pressure ${ }^{5}$ or threaten Internet users, for example with costly legal proceedings based on ill-founded infringement claims that stand no real chance of success $^{6}$. In this perspective, copyright trolling resembles another phenomenon, namely "threatening debt collection". When the offenders bear no title to the author's economic rights they try to enforce, their behavior seems dubious. Contrarily, when a request for compensation in connection with copyright infringement is issued to the offender by the actual copyright owner, such an action constitutes legitimate enforcement of rights, even if the request contains elements such as a threat of litigation. The owner's actions cannot be described as copyright trolling, which is a term tainted by negative connotations. Even if the manner of right enforcement may seem dubious at times, the law does not require any particular form or content

\footnotetext{
${ }^{1}$ Sag, M. (2015). Copyright Trolling, An Empirical Study. Iowa Law Review, Vol. 100, Issue 3, 1 March 2015, p. 1113.

2 Jankowska, M. (2017). Ustawa, op.cit., p. 542, Curran, L.S. (2013). op.cit. p. 172, Balganesh, S. (2013). op.cit. p. 6.

${ }^{3}$ Curran, L. S. (2013). op.cit., p. 172.

${ }^{4}$ Greenberg, B.A. (2014). op.cit., p. 59.

${ }^{5}$ Wrzeszcz, O. (2016). op.cit. p. 45.

${ }^{6}$ Collins Hoffman, P.-Ch. (2015). Non-Commercial Online Copyright Infringement in Canada: The Challenge of Balancing the Copyright Owners' Interests Against Those of Internet Users. Internet and E-Commerce Law in Canada, Vol. 16, No. 1, 2015, pp. 1-8.
} 
of a payment request ${ }^{1}$. Similarly, copyright trolling does not occur if, in the case of an actual copyright infringement, the entitled owner seeks compensation from an innocent party. Since the Copyright Law does not explicitly ascribe the burden of proof, it rests on the party which attributes legal effects to a fact (compare: Art. 6 of the CC). If the entitled party fails to prove that the accused committed the infringement, the claim will be ineffective.

As previously indicated, the actions of copyright trolls are assessed in line with i.a. their intentions ${ }^{2}$. A copyright troll takes action only to gain (undue) profit and not to pursue claims in connection with copyright infringement. Thus, an entity which pursues claims in connection with copyright infringement is not automatically a copyright troll ${ }^{3}$. Ill intentions of the entitled party may become apparent if the claimant sends requests for payments to a large number of random people, even though even such actions may be explained by the potential troll as a mere joke, a frivolous declaration of intent, or even scientific research. Since motives are always subjective, proving them may not only be difficult but impossible. Thus, in the case of copyright trolling, the legislator could consider reversing the burden of proof, i.e. obliging the copyright troll to prove that their actions were within the law.

Note that copyright trolling is not a copyright infringement but an action of exploiting copyright infringement and the related protection measures to obtain material gain (extort money). As such, the term combines the category of copyright and the term "troll", whereas the term "troll" itself is often used in various combinations to denote a repetitive, disruptive behavior by an individual toward other individuals or groups. Thus, the definition of copyright trolling rests on the intentions (motives) that drive the civil-law entity in question.

\subsection{Civil-law assessment of the phenomenon}

It is interesting to consider whether copyright trolling results in the conclusion of a contract (juridical act) or does it involve a delict? Solution of this dilemma impacts the legal consequences, i.e. the determination of the basis for returning the performance rendered / indemnification liability.

\subsubsection{The declaration of intent}

It seems reasonable to claim that both the declaration of a copyright troll and the recipient's response bear the characteristics of a declaration of intent ${ }^{4}$. Despite the absence of infringement or the wish to actually pursue claims, a copyright troll acts with the intention of concluding a specific contract. In turn, the recipient who renders the performance - because in their perspective, the action constitutes a performance - declares their intent to conclude the said contract under the mistaken impression that they are guilty of the infringement and their actions would repair

\footnotetext{
${ }^{1}$ Compare: Wrzeszcz, O. (2016). op.cit., p. 45.

${ }^{2}$ For example: Balganesh, S. (2013). p. 6.

${ }^{3}$ The owner of the author's economic rights may: 1) mistakenly believe that their rights have been infringed upon or 2) pursue claims against the wrong person. Furthermore, the civil-law entity in question may be mistaken in the belief that they bear a title to the author's economic rights.

${ }^{4}$ For more information on the declaration of intent, see: Mi, J. (2007). Analysis on declaration of intent. Frontiers of Law in China 2, No. 3, 2007, pp. 446-463.
} 
the damage caused. Thus, both parties declare the intent to produce specific legal effects, even though the existence of a consensus is not self-evident.

Assuming that the parties issued declarations of intent, copyright trolling does not involve an ostensible act, i.e. the apparent conclusion of a contract, but an effective though (definitely) defective juridical act. Circumstances imply the conclusion of an adhesion contract, i.e. a unilaterally formulated contract proposal which the other party can only accept with no modifications ${ }^{1}$. Such a contract is characteristic in the lack of negotiations or an officially formulated consensus ${ }^{2}$. A copyright troll proposes to conclude a contract described, for instance, as a settlement ${ }^{3}$ or an agreement for the non-initiation of legal proceedings. However, copyright trolling certainly fails to meet the structural requirements of a settlement foreseen in the Polish legislation (compare: Art. 917 et seq. of the CC). Most importantly, a settlement may be concluded in the event of a dispute or uncertainty between the parties to a legal relationship regarding their claims ${ }^{4}$. A settlement cannot be concluded between parties that knowingly aim to create a hitherto non-existent legal relationship ${ }^{5}$. The settlement may concern a non-existing legal relationship only when both parties are convinced of its existence or have doubts on the issue ${ }^{6}$. The settlement aims to partly amend the existing relationship by way of mutual concessions ${ }^{7}$. Meanwhile, in accordance with the assumptions made in this paper, a copyright troll and a recipient are not bound by any legal relationship. The troll suggests the existence of such a (fictitious) relationship and invokes it to demand a concession from the recipient. For one party, the agreement would involve the recognition of the claim and the payment of an appropriate sum by the offender (the recipient), for the other - a reduction of the sum in comparison with the damages or the compensation that could be ordered by the court and a partial or total waiver of claims ${ }^{8}$. It is evident that the troll's declaration regarding the reduction and the waiver of claims do not constitute concessions, even though the recipient remains under this impression. An agreement wherein one party admits to causing damage by having committed copyright infringement (which is not true) and agrees to repair said damage by paying the suggested sum does not fulfil the requirements on the legal structure of a settlement. Assuming that copyright trolling involves a juridical act, the act in question could be an agreement other than the settlement of an innominate contract.

${ }^{1}$ Radwański, Z., Olejniczak, A. (2005). Zobowiązania - część ogylna, Warsaw: C.H. Beck 2005, p. 117.

${ }^{2}$ Bednarek, M. (2006). System Prawa Prywatnego, Prawo zobowiązań - część ogylna, E. Łętowska (ed.), Warsaw: C.H. Beck, 2006, p. 552.

${ }^{3}$ Wrzeszcz, O. (2016). op.cit. p. 45.

${ }^{4}$ Pyziak-Szafnicka, M. (2004). System Prawa Prywatnego, Prawo zobowiązań - część szczegyłowa, J. Panowicz-Lipska (ed.), Warsaw: C.H. Beck, 2004, p. 854.

${ }^{5}$ Ibidem, p. 871.

${ }^{6}$ Ibidem.

${ }^{7}$ Jezioro, J. (2013). Kodeks cywilny. Komentarz, E. Gniewek, P. Machnikowski (eds.), Warsaw: C.H. Beck, 2013, p. 1505, Gawlik, Z. (2014). Kodeks cywilny. Komentarz. Tom III. Zobowiązania część szczegylna, A. Kidyba (ed.), available in lex database 2014.

${ }^{8}$ Wrzeszcz, O. (2016). op.cit., p. 57. 


\subsubsection{Legal basis for return of the performance rendered/indemnification liability}

If a person receives a request for payment from a copyright troll and has rendered the performance, what should they do next? Idleness would result in sustaining loss and leaving the troll unpunished. Polish legislation does not foresee any specific regulation on the return of performance in such circumstances.

As already established in this paper, the declaration of intent made by the recipient is defective and would probably be classed as an error (Art. 84 of the CC) $)^{1}$, even though there are grounds for also considering a threat (Art. 87 of the CC). It is assumed that the civil-law entity has made the declaration under the influence of an error and the content of the juridical act did not reflect their perception thereof. Such perception may concern not only the essentialia negotii of the juridical act in question but also its other elements, i.e. the type of juridical act, the facts referred to in the declaration, legal norms applicable to the act, or its legal effects ${ }^{2}$. In the case of an error as to the content of a juridical act, one may free himself from the legal consequences of their declaration of intent (Art. 84 of the CC). Freeing oneself from the legal consequences comes into being by a declaration made to that person in writing (Art. 88.1 of the CC). The entitlement to free oneself shall expire upon the lapse of a year from its discovery (Art. 88.2 of the CC). As a result, the copyright troll shall be obliged to return the performance. The basis for the return is provided by regulations on unjust enrichment. Although in the view of the recipient, invoking the defect of the declaration is a good solution, legal effects of such qualification of the act fail to do justice to the factual situation created by the copyright troll. Above all, the behavior of a copyright troll bears the hallmarks of illegality, which is not in any way sanctioned if the recipient claims an error.

The behavior of a copyright troll bears the hallmarks of illegality because it breaches Art 286.1 of the Polish Penal $\operatorname{Code}^{3}$ (a conflict with the law) and the principle of community coexistence. Thus, it is Art. 58 of the $\mathrm{CC}$ that provides a more suitable legal basis for assessment of the facts. In the framework of copyright trolling, the recipient renders the performance under the mistaken belief that they pay a debt (damages for copyright infringement), whereas they actually perform an obligation which has never existed and whereto they have never been a party ${ }^{4}$. Thus, in accordance with Art. 58 of the CC, such an action should be qualified firstly

${ }^{1}$ Gordley, J. (2004). Mistake in Contract Formation. American Journal of Comparative Law 52, No. 2, 2004, pp. 433-468.

${ }^{2}$ Wrzesiński, P. (2015). Uchylenie się od skutkyw prawnych umowy ubezpieczenia na życie z ubezpieczeniowym funduszem kapitałowym na podstawie błędu lub podstępu. Prawo Asekuracyjne 2, pp. 39-55.

${ }^{3}$ Art. 286.1. Anyone who, intending to achieve a material benefit, causes another person to unfavorably dispose of their property, or the property of a third party, by misleading the person, or by taking advantage of a mistake or an inability to properly understand the action undertaken, shall be subject to the penalty of deprivation of liberty for between 6 months to 8 years; Act of June, 6 1997, the Penal Code, Dz.U. 2019, item 1950, hereinafter: the PC.

${ }^{4}$ Compare: Sokołowski, T. (2014). Kodeks cywilny. Komentarz. Tom III. Zobowiązania - część ogylna, A. Kidyba (ed.), available in lex database 2014. 
as contrary to the law and secondly as contrary to the principles of community coexistence (compare: Art. 5 of the CC), and consequently as an invalid juridical act. The consequences of declaring invalidity are the same as in the case of claiming error, i.e. involve the obligation to return the performance rendered under the regulations on unjust enrichment.

Incidentally, note that compliance with the demand of a copyright troll may be considered a special case of unjust enrichment, i.e. undue performance (condictio indebiti) (Art. 405 in conjunction with Art. 410.2 of the CC). The source of unjust enrichment would be the actions of the payer (solvens) to render the performance to the benefit of the unjustly enriched (accipiens). The payer acts under the impression that the performance is rendered under an existing obligation, whereas they are not and never have been party to said obligation ${ }^{1}$. For the application of Art. 410.2 of the $\mathrm{CC}$, the cause of invalidity is immaterial (so it could be a conflict with the principles of community coexistence). Note that a claim for undue performance becomes due as at the date of rendering said (undue) performance. Legislation foresees neither maturity dates for the claims regarding the return of performance, nor time limits for rendering the undue performance. The claim expires under general conditions (Art. 118 of the CC).

Meanwhile, an analysis of the civil law reveals yet another solution (besides applying Art. 84 of the CC or Art. 58 of the CC). Possibly, inducing the recipient to conclude a contract and make an unfavorable disposition of their property under the conditions described should generally be regarded as an illegal and forbidden act (a delict), contrary to the applicable legal order and even more so as the existence of a consensus in the circumstances of copyright trolling is dubious. Actions that aim to treacherously mislead the party and inspire fear may constitute an illegal act, which fulfills the premises of Art. 415 of the CC provided that any damage occurs². The damage in question is the rendering of a performance (reduction in the property of the recipient) to the benefit of the copyright troll. In the obligation relationship, the performance that involves redressing the damage caused by an illegal act constitutes the original performance. The compensation cannot exceed the value of damage and thus become a punishment for the offender.

Furthermore, it is interesting to consider whether copyright trolling and other forms of "threatening debt collection" constitute actions that infringe upon personal interests such as privacy, peace, the right not to be disturbed, the inviolability of the home. If confirmed, such a hypothesis would provide an additional opportunity to demand the cessation of the action, the removal of its consequences, pecuniary compensation, or a payment of an adequate amount of money for a specified community purpose (Art. 23, 24 of the CC). Continuing in this vein, it is also interesting to consider whether the actions of the copyright troll involve multiple

${ }^{1}$ Ibidem; judgment of the Supreme Court of December 1, 1999, case reference No. I CKN 203/98 (lex database, No. 50687).

${ }^{2}$ Lewaszkiewicz-Petrykowska, B. (1971). Uwagi o konstrukcji wad oświadczenia woli w Kodeksie cywilnym. Studia Prawno-Ekonomiczne No. 6, 1971, p. 69. 
attempts at establishing contact, multiple texts and email, many phone calls, etc. Depending on its intensity, copyright trolling may fall into the category of harassment. Such qualification would veer the deliberations towards criminal-law regulations relating to the so-called stalking (compare: Art. 190a of the $\left.\mathrm{PC}^{1}\right)^{2}$.

Finally, in the case of consumers, it is desirable to notify the President of the Office of Competition and Consumer Protection ${ }^{3}$. This authority may (should) initiate proceedings to ban similar actions and punish the copyright troll. In addition, since President of the Office of Competition and Consumer Protection has the authority to publish consumer warnings, he should take necessary measures to warn other participants in the market against the practices of the given copyright troll.

\section{Conclusions}

Note that the practice of threatening with debt collection ${ }^{4}$, which generally can be exemplified by copyright trolling, poses a major problem in modern times. It is common to hear stories about debts that never existed or expired, entities posing as other organizations and calling for the payment of a fictitious fee, threats of auditing and financial consequences, also in the area of copyright ${ }^{5}$. It seems that the issue needs a legislative solution in the field of private law $^{6}$. Due to the absence of any special regulation on copyright trolling, the matter is governed by general provisions of the civil law which, as demonstrated, do not provide the recipient of a request for payment with an unambiguous legal basis for demanding the return of the performance rendered. It seems reasonable to claim either a defective declaration of intent or the invalidity of the juridical act, and thus invoke the provisions on unjust enrichment. In the framework of civil law, rendering the performance to the benefit of a copyright troll may also be regarded as damage sustained by the recipient as a

\footnotetext{
${ }^{1}$ Art. 190(a).1 Whoever causes justified feeling of threat or significantly infringes the person's privacy through persistent harassment shall be subject to the penalty of deprivation of liberty for up to 3 years.

2 Bieniek E., Lewandowski P. (2012). Freedom from being stalked as a personal right. The Milestones of Law in the area of Europe 2012“, 2nd part, Comenius University in Bratislava, Faculty of Law, 2012, pp. 816-820.

${ }^{3}$ https://www.uokik.gov.pl/about_us.php

${ }^{4}$ Debt collection involves the pursuance of claims with the use of legal measures (foreseen under and within the limits of the law), although the actions do not require an official form; in colloquial language, debt collection involves also non-legal measures, such as physical force or mental pressure, e.g. based on inspiring fear, Podel, W. (2014). Windykacja. Dla wierzycieli, firm windykacyjnych i kancelarii prawnych. Skuteczne praktyki. Warsaw: Difin, 2014, pp. 36-37, 397.

${ }^{5}$ For instance, the Patent Office of the Republic of Poland has issued on its website a warning regarding a fraud that involves sending misleading payments requests or invoices related to the registration of trademarks, inventions, industrial designs, and utility models. In its actions, the Office intended to raise the awareness of participants in the economy. Note that the Office additionally called the entities involved to stop the practice and informed the Prosecutor's Office about the issue, http://www.uprp.pl/ostrzezenie-przed-wprowadzajacymi-w-blad-wezwaniami-do-zaplaty-lubfakturami/Lead51,795,1375,7,index,pl,text/ (19.11.2019).

6 Since the paper analyses copyright trolling in the framework of civil law, criminal-law considerations have been omitted.
} 
result of a delict. Therefore, the recipients have a certain choice of the legal basis, which additionally complicates their difficult situation.

The analysis leads to a conclusion that the legislator needs to turn its attention to similar phenomena. Firstly, copyright trolling (or even the broader phenomenon of threatening debt collection) requires a legal definition. Secondly, appropriate regulations on civil-law sanctions need to be introduced. A prerequisite for such legislative action is the identification of specific cases of trolling ${ }^{1}$, which should not, however, lead to a typically casuistic wording. The introduction of a new regulation would not only help the judges and other interested parties but, above all, should stop copyright trolls.

\section{References}

\section{Legal acts}

1. Act of April 23, 1964 The Civil Code (consolidated text, Journal of Laws of 2019, item. 1145, as amended).

2. Act of February 4, 1994 Law on Copyright and Neighbouring Rights (consolided text, Journal of Laws of 2019, item 1231, as amended).

3. Act of June, 6 1997, the Penal Code, Dz.U. 2019, item 1950.

\section{Bibliography}

4. Balganesh, S. (2013). The Uneasy Case Against Copyright Trolls. 86 Southern California law review, 723 (2013) available on http://ssrn.com/abstract=2150716.

5. Bednarek, M. (2006). System Prawa Prywatnego, Prawo zobowiązań - część ogylna, E. Łętowska (ed.), Warsaw: C.H. Beck, 2006.

6. Bieniek, E., Lewandowski, P. (2012). Freedom from being stalked as a personal right. The Milestones of Law in the area of Europe 2012, $2^{\text {nd }}$ part, Comenius University in Bratislava, Faculty of Law, 2012.

7. Bogdalski, P. (2003). Środki ochrony autorskich praw majątkowych oraz ich dochodzenie w świetle prawa polskiego, Warsaw: Wolters Kluwer, 2003.

8. Collins Hoffman, P.-Ch. (2015). Non-Commercial Online Copyright Infringement in Canada: The Challenge of Balancing the Copyright Owners' Interests Against Those of Internet Users, Internet and E-Commerce Law in Canada, Vol. 16, No. 1, 2015.

9. Curran, L.S. (2013). Copyright Trolls, Defining the Line Between Legal Ransom Letters and Defending Digital Rights: Turning Piracy into a Business Model or Protecting Creative from Internet Lawlessness? 13 The John Marshall Review of Intellectual Property Law 170, 2013.

10. Gawlik, Z. (2014). Kodeks cywilny. Komentarz. Tom III. Zobowiązania - część szczegylna, A. Kidyba (ed.), available on lex database 2014.

11. Gordley, J. (2004). Mistake in Contract Formation. American Journal of Comparative Law 52, no. 2, 2004.

12. Greenberg, B.A. (2014). Copyright trolls and presumptively fair uses. University of Colorado Law Review, Vol. 85, 2014.

13. Grzybczyk, K. (2019). Ikony popkultury a prawo własności intelektualnej. Jak znani i sławni chronią swoje prawa, Warsaw: Wolters Kluwer, 2019.

14. Jankowska, M. (2011). Autorstwo i prawo do autorstwa, Warsaw: Wolters Kluwer, 2011.

15. Jankowska, M. (2017). Ustawa o prawie autorskim i prawach pokrewnych. Komentarz, P. Ślęzak (ed.), Warsaw: C.H. Beck, 2017. 
16. Jezioro, J. (2013). Kodeks cywilny. Komentarz, E. Gniewek, P. Machnikowski (eds.), Warsaw: C.H. Beck, 2013.

17. Lewaszkiewicz-Petrykowska, B. (1971). Uwagi o konstrukcji wad oświadczenia woli w Kodeksie cywilnym. Studia Prawno-Ekonomiczne no. 6, 1971.

18. Mi, J. (2007). Analysis on declaration of intent. Frontiers of Law in China 2, no. 3, 2007.

19. Nowicka, A. (2013). System Prawa Prywatnego, Prawo autorskie, vol. 13, J. Barta (ed.), Warsaw: C.H. Beck, 2013.

20. Podel, W. (2014). Windykacja. Dla wierzycieli, firm windykacyjnych i kancelarii prawnych. Skuteczne praktyki, Warsaw: Difin, 2014.

21. Preussner-Zamorska, J., Marcinkowska, J. (2013). System Prawa Prywatnego, Prawo autorskie, Vol. 13, J. Barta (ed.), Warsaw: C.H.Beck, 2013.

22. Pyziak-Szafnicka, M. (2004). System Prawa Prywatnego, Prawo zobowiązań - część szczegyłowa, J. Panowicz-Lipska (ed.), Warsaw: C.H. Beck, 2004.

23. Radwański, Z., Olejniczak, A. (2005). Zobowiązania - część ogylna, Warsaw: C.H. Beck 2005.

24. Sag, M. (2015). Copyright Trolling, An Empirical Study. Iowa Law Review, Volume 100, Issue 3, 1 March 2015, p. 1113.

25. Ślęzak, P. (2007). Dziedziczenie praw majątkowych w świetle polskiego prawa autorskiego. Rejent no 1, 2007.

26. Sokołowski, T. (2014). Kodeks cywilny. Komentarz. Tom III. Zobowiązania - część ogylna, A. Kidyba (ed.), available on lex database 2014.

27. Wall, D.S. (2015). Copyright trolling and the policing of intellectual property in the shadow of law. The SAGE Handbook of Intellectual Property, M. David and D. Halbert, (eds), London: SAGE, 2015.

28. Wrzesiński, P. (2015). Uchylenie się od skutkyw prawnych umowy ubezpieczenia na życie z ubezpieczeniowym funduszem kapitałowym na podstawie błędu lub podstępu. Prawo Asekuracyjne 2, 2015.

29. Wrzeszcz, O. (2016). Trolling prawnoautorski (copyright trolling). Zeszyty Naukowe Uniwersytetu Jagiellońskiego. Prace z prawa własności intelektualnej z. 134, 2016.

30. Zygmunt, J. (2017). Przesyłanie plikyw za pośrednictwem sieci peer-to-peer a rozpowszechnienie utworu w rozumieniu prawa autorskiego. Zeszyty Naukowe Uniwersytetu Jagiellońskiego no. 1, 2017.

\section{Other}

31. URL: http://www.uprp.pl/ostrzezenie-przed-wprowadzajacymi-w-blad-wezwaniami-do-zaplaty-lub-fakturami/Lead51,795,1375,7,index,pl,text/ (19.11. 2019).

32. URL: https://www.gov.uk/government/publications/letters-alleging-online-copyright-infringement/letters-alleging-online-copyright-infringement.

33. URL: https://www.uokik.gov.pl/about_us.php.

\section{Judgements}

34. Judgement of the Supreme Court of December 1, 1999, case reference no I CKN 203/98 (lex database, no. 50687).

35. Judgement of the Constitutional Tribunal of June 23, 2015, case reference no. SK 32/14 (lex database OTK-A 2015/6/84).

36. Judgement of the Administrative Court in Poznań of November 7, 2007, case reference no. I ACa 800/07 (lex database, no. 370747).

Левандовска E., кандидат юридических наук, кафедра гражданского права и международного частного права, факультет права и администрирования, Варминско-Мазурский университет в Ольштыне.

e-mail: ewa1bieniek@gmail.com ; e.lewandowska@uwm.edu.pl ; ORCID 0000-0001-8369-6290 


\section{О троллинге авторских прав в рамках гражданского законодательства}

Анализируется троллинг авторских прав в рамках неправомерных требований о возмещении вреда за нарушение экономических прав автора, то есть когда: 1) не произошло нарушения экономических прав, или 2) иск подан против неправильных органов власти, или 3) истеи, не имеет права на предбявление иска в суд. Изложены случаи нарушения экономических прав автора в польском законодательстве и меры защить, доступные правомочной стороне в случае нарушения. Кроме того, обсуждается термин «авторский троллинг» и его область применения, предлагается оценка этого явления в рамках гражданского законодательства, акцентируя внимание прежде всего на правовой основе возвращения выполнения/возмещения вреда. Отмечается, что обстоятельства троллинга авторских прав позволяют заявить о нарушениях в интересах личных интересов. Статья направлена на то, чтобы способствовать росту литературы о троллинге авторских прав. Автор надеется начать осознанную дискуссию на основе исследований, которая могла бы иметь дополнительную пользу в образовании общественности по этому вопросу.

Ключевые слова: троллинг авторских прав; экономические права автора; декларация о намерениях; договор; деликт; личные интересы.

Рекомендоване цитування: Lewandowska E. On copyright trolling in the framework of civil law. Проблеми законності. 2020. Вип. 150. С. 277-291. doi: https://doi.org/10.21564/2414-990x.150. 205798.

Suggested Citation: Lewandowska, E. (2020). On copyright trolling in the framework of civil law. Problemy zakonnosti - Problems of Legality, issue 150, 277-291. doi: https://doi.org/ 10.21564/2414-990x.150.205798.

Надійшла до редколегї 18.06.2020 p. 